\title{
Nasal Cavity and Ethmoid Sinus Cancer Pathologic TNM Finding v7
}

National Cancer Institute

\section{Source}

National Cancer Institute. Nasal Cavity and Ethmoid Sinus Cancer Pathologic TNM

Finding v7. NCI Thesaurus. Code C89106.

A pathologic finding about one or more characteristics of nasal cavity and ethmoid sinus cancer, following the rules of the TNM AJCC V7 classification system. The pathologic staging requires the use of all information obtained in clinical staging and in histologic study of the surgically resected specimens. The surgeon's evaluation of gross unresected residual tumor must also be included. (from AJCC 7th Ed.) 